\title{
PERBANDINGAN MEDIA AUDIOVISUAL DAN CERAMAH TERHADAP SIKAP SISWA TENTANG PENTINGNYA KONSUMSI SAYUR DAN BUAH
}

\author{
Mona Hastuti ${ }^{1}$, Kintoko Rochadi ${ }^{2}$, Etti Sudaryati ${ }^{3}$ \\ ${ }^{1}$ Program Studi S2 Ilmu Kesehatan Masyarakat Universitas Sumatera Utara \\ ${ }^{2}$ Fakultas Kesehatan Masyarakat Universitas Sumatera Utara \\ ${ }^{3}$ Fakultas Kesehatan Masyarakat Universitas Sumatera Utara \\ Email: monahastuti77@gmail.com ${ }^{1}$
}

\begin{abstract}
The importance of consuming fruit and vegetables is commonly neglected by the Indonesian people. Only 6.4\% of adolescents at the age of 10-14 consume fruit and vegetables about 5 portions or more per day while the remaining 93.6\% fewer than 5 portions. It is probably caused by their lack of knowledge and negative attitude toward it so that health promotion, using audiovisual, is needed. The research method used quasi experimental method with group pretest-posttest design. It was conducted at Integrated Islamic Junior High School Al Musabbihin and Namira Medan. The population was 58 students consisted of 28 at Integrated Islamic Junior High School Al Musabbihin and 30 at Namira School. The data were analyzed by using univariate and bivariate analysis with paired-sample t-test at significance level of 95\% ( $\alpha=0.05)$. Result and Discussion of statistic test showed that there was significant difference in attitude between the students at Al Musabbihin School and Namira School about the importance of consuming fruit and vegetables. The conclusion of the research is that audio visual media is more effective to change students' attitudes become more positive about the importance of vegetable and fruit consumption in Al Musabbihin School and lecturer method is effective at Namira School Medan.
\end{abstract}

Keyword: Audiovisual Media, Lecture, Attitude, Vegetables, Fruit

\section{PENDAHULUAN}

Bidang kesehatan sedang mengalami transisi epidemiologi yang menyebabkan terjadinya perubahan pola penyakit dari penyakit infeksi ke penyakit tidak menular (PTM). Penyakit tidak menular seperti penyakit kardiovaskular, kanker, penyakit pencernaan, pernapasan kronis, dan Diabetes Melitus (DM) menyebabkan kematian dan membunuh sekitar 35 juta manusia setiap tahunnya, atau $60 \%$ dari seluruh kematian secara global, dengan $80 \%$ prevalensi pada negara berkembang. World Health Organization (WHO) memprediksikan total kematian yang disebabkan oleh penyakit tidak menular akan meningkat sampai $17 \%$ dalam 10 tahun. Penyakit tidak menular berhubungan dengan genetik, lingkungan, dan yang paling penting adalah gaya hidup seperti merokok, konsumsi alkohol, pola makan (diet) yang buruk, dan kurangnya aktifitas (Warganegara \& Nur, 2016).

Pentingnya mengonsumsi buah dan sayur masih kurang disadari oleh sebagian besar penduduk Indonesia. Hasil Riset Kesehatan Dasar (Riskesdas) pada tahun 2013, proporsi rerata nasional perilaku kurang konsumsi sayur dan buah 93,5\%. Tingginya angka kurang konsumsi sayur dan buah masyarakat mengakibatkan penyakit pencernaan dan sembelit yang bisa fatal bagi kesehatan. 
Khusus pada remaja usia 10-14 tahun hanya $6,4 \%$ yang mengkonsumsi buah dan sayur di Indonesia sebanyak 5 porsi atau lebih per hari selebihnya kurang dari 5 porsi (Kemenkes RI, 2013).

Upaya pemerintah untuk menggalakkan konsumsi sayur dan buah sehari-hari dibuktikan dari salah satu indikator Perilaku Hidup Bersih dan Sehat (PHBS) di Rumah Tangga yaitu makan buah dan sayur setiap hari. Kemenkes RI (2016) juga menyatakan bahwa salah satu tahap awal dari program Gerakan Masyarakat Hidup Sehat (GERMAS) adalah mengonsumsi sayur dan buah yang dimulai dari diri sendiri dan keluarga.

Hasil survei awal tentang konsumsi sayur dan buah pada siswa kelas VII A SMPIT Al Musabbihin Medan diperoleh informasi pada umumnya siswa kurang mengonsumsi sayur. Hal ini dibuktikan dari jawaban 17 siswa terhadap daftar pertanyaan pada survei awal, diketahui sebanyak 12 siswa jarang makan sayur dan buah $(70,58 \%)$ dan sisanya 5 orang siswa selalu makan sayur dan buah $(29,42 \%)$. Hasil wawancara dengan siswa, diketahui bahwa dari 17 siswa, 10 siswa kurang mengetahui manfaat makan sayur dan buah bagi kesehatan. Sikap terhadap konsumsi sayur dan buah siswa juga cenderung masih rendah, terbukti dari jawaban responden yang menyatakan kurang peduli dengan anjuran ibu untuk mengonsumsi sayur dan buah secara rutin.
Kebiasaan konsumsi sayur dan buah siswa berdasarkan hasil wawancara tidak berbeda jauh di SMPIT Namira Medan. Hasil wawancara dengan 14 siswa (7 siswa kelas VII reguler dan 7 siswa kelas VII plus) diperoleh bahwa 8 siswa $(53,3 \%)$ kurang mengetahui manfaat sayur dan buah. Mereka terbiasa tidak menghabiskan sayuran di piring sewaktu makan di kantin sekolah. Siswa yang membawa bekal makanan dari rumah, biasanya juga tidak menghabiskan sayuran dengan alasan rasa sayuran tersebut tidak enak. Sedangkan sewaktu jajan di sekolah mereka lebih suka membeli minuman siap saji seperti bakso, mie sop, mie goreng, bakso bakar, minuman bersoda daripada membeli buah-buahan. Padahal harganya sepotong buah lebih murah daripada makanan dan minuman cepat saji tersebut.

Hasil wawancara dengan pihak kedua sekolah tersebut, diketahui bahwa kegiatan promosi kesehatan berkaitan dengan konsumsi sayur dan buah pada siswa belum pernah dilaksanakan baik oleh petugas kesehatan dari Puskesmas ataupun mahasiswa yang melakukan penelitian. Upaya yang dilakukan pihak sekolah selama ini hanya memberi materi melalui mata pelajaran yang berkaitan dengan konsumsi sayur dan buah di dalam kelas.

Promosi kesehatan terhadap konsumsi sayur dan buah pada remaja merupakan tantangan tersendiri karena banyak remaja memang tidak memiliki minat untuk mengonsumsi sayur dan 
buah. Promosi kesehatan dengan media audiovisual dikarenakan siswa usia remaja saat ini lebih senang menonton tayangan gambar bergerak (film) terutama film animasi karena remaja masih senang melihat film animasi kartun yang menjadi kebiasaan dari sejak kecil. Film animasi sebagai sarana informasi dapat menyampaikan informasi yang baik dan benar, sesuai dengan kenyataan, tidak direkayasa, masuk akal atau dibesarbesarkan. Film animasi sebagai sarana pembelajaran dapat memberikan pembelajaran yang positif sehingga dapat ditiru dan digunakan sebagai bahan ajar di sekolah dengan tujuan dapat meningkatkan pengetahuan, penanaman kognitif, psikomotorik dan pembentukan afektif. Tujuan penelitian ini untuk menganalisis perbedaan media audiovisual dan sikap siswa pentingnya kosumsi sayur dan buah.

\section{METODE PENELITIAN}

Jenis penelitian ini adalah penelitian quasi experimental dengan group pretest pos ttest design. Penelitian ini dilakukan di SMPIT Al Musabbihin dan SMPIT Namira. Populasi dalam penelitian ini sebanyak 58 orang dan seluruhnya dijadikan sampel (28 orang di SMPIT Al Musabbihin dan 30 orang di SMPIT Namira). Analisis data dilakukan dengan cara analisis univariat dan analisis bivariat dengan uji $\mathrm{t}$ dependen (pairedsample $t$ test $)$ pada tingkat kepercayaan $95 \%(\alpha=0,05)$.

\section{HASIL PENELITIAN}

\section{Karakteristik Responden}

Karakteristik responden meliputi umur, jenis kelamin, suku, dan pendapatan keluarga per bulan. Selengkapnya dapat dilihat pada tabel berikut ini.

Tabel 1 Karakteristik Responden

\begin{tabular}{|c|c|c|c|c|}
\hline \multirow[t]{2}{*}{ Karakteristik } & \multicolumn{2}{|c|}{$\begin{array}{c}\text { SMPIT Al } \\
\text { Musabbihi } \\
\text { n } \\
\end{array}$} & \multicolumn{2}{|c|}{$\begin{array}{l}\text { SMPIT } \\
\text { Namira }\end{array}$} \\
\hline & Jlh & $\%$ & $\begin{array}{l}\mathbf{J l} \\
\mathbf{h}\end{array}$ & $\%$ \\
\hline \multicolumn{5}{|l|}{ Umur: } \\
\hline a. 11 tahun & 1 & 3,6 & 16 & 53,3 \\
\hline b. 12 tahun & 19 & 67,9 & 13 & 43,4 \\
\hline c. 13 tahun & 8 & 28,5 & 1 & 3,3 \\
\hline \multicolumn{5}{|l|}{ Jenis Kelamin: } \\
\hline a. Laki-laki & 12 & 42,9 & 12 & 40,0 \\
\hline b. Perempuan & 16 & 57,1 & 18 & 60,0 \\
\hline \multicolumn{5}{|l|}{ Suku : } \\
\hline a. Karo & 2 & 7,1 & 1 & 3,3 \\
\hline b. Batak & 5 & 17,9 & 4 & 13,3 \\
\hline c. Jawa & 12 & 42,9 & 12 & 40,0 \\
\hline d. Padang/ & 3 & 10,7 & 3 & 10,0 \\
\hline Minang & 0 & 0,0 & 3 & 10,0 \\
\hline e. Mandailing & 0 & 0,0 & 1 & 3,3 \\
\hline f. Banten & 2 & 7,1 & 4 & 13,3 \\
\hline $\begin{array}{ll}\text { g. } & \text { Aceh } \\
\text { h. } & \text { Melayu }\end{array}$ & 4 & 14,3 & 2 & 6,7 \\
\hline \multicolumn{5}{|l|}{ Pendapatan Orang } \\
\hline tua : & 0 & 0,0 & 1 & 3,3 \\
\hline $\begin{array}{l}\text { a. <Rp.2.528.815.- } \\
\text { b. > Rp.2.528.815.- }\end{array}$ & 28 & 100,0 & 29 & $\begin{array}{c}96 \\
7\end{array}$ \\
\hline
\end{tabular}

\section{Sikap Siswa (Pretest)}

Berdasarkan hasil penelitian, sikap siswa sebelum diberi perlakuan (pretest) dapat dilihat pada tabel berikut ini.

Tabel 2 Distribusi Frekuensi Sikap Siswa Sebelum Diberi Perlakuan (Pretest)

\begin{tabular}{ccccc}
\hline \multirow{2}{*}{$\begin{array}{c}\text { Sikap } \\
\text { (Pretest) }\end{array}$} & \multicolumn{2}{c}{$\begin{array}{c}\text { SMPIT Al } \\
\text { Musabbihin } \\
\text { (Audiovisual) }\end{array}$} & \multicolumn{2}{c}{$\begin{array}{c}\text { SMPIT } \\
\text { Namira } \\
\text { (Ceramah) }\end{array}$} \\
\cline { 2 - 5 } & $\mathbf{f}$ & $\mathbf{\%}$ & $\mathbf{f}$ & $\%$ \\
\hline Positif & 11 & 39,3 & 9 & 30,0 \\
Negatif & 17 & 60,7 & 21 & 70,0 \\
\hline Jumlah & $\mathbf{2 8}$ & $\mathbf{1 0 0 , 0}$ & $\mathbf{4 0}$ & $\mathbf{1 0 0 , 0}$
\end{tabular}

Sikap siswa SMPIT Al Musabbihin dan SMPIT Namira tentang pentingnya 
konsumsi sayur dan buah sebelum diberi pendidikan kesehatan menggunakan media audiovisual dan ceramah (pretest) menunjukkan bahwa sebagian besar sikap siswa di SMPIT Al Musabbihin dalam kategori negatif $(60,7 \%)$, bersikap positif $(39,3 \%)$. Sikap siswa di SMPIT Namira sebagian besar juga negatif $(70,0 \%)$, bersikap positif (30,0\%).

\section{Sikap Siswa (Posttest)}

Berdasarkan hasil penelitian, sikap siswa setelah diberi perlakuan (posttest) dapat dilihat pada tabel berikut ini.
Tabel 3 Distribusi Frekuensi Sikap Siswa Sebelum Diberi Perlakuan (Posttest)

\begin{tabular}{ccccc}
\hline \multirow{2}{*}{$\begin{array}{c}\text { Sikap } \\
\text { (posttest) }\end{array}$} & $\begin{array}{c}\text { SMPIT Al } \\
\text { Musabbihin } \\
\text { (Audiovisual) }\end{array}$ & \multicolumn{2}{c}{$\begin{array}{c}\text { SMPIT } \\
\text { Namira } \\
\text { (Ceramah) }\end{array}$} \\
\cline { 2 - 5 } & $\mathbf{f}$ & $\mathbf{\%}$ & $\mathbf{f}$ & $\mathbf{\%}$ \\
\hline Positif & 26 & 92,9 & 23 & 76,7 \\
Negatif & 2 & 7,1 & 7 & 23,3 \\
\hline Jumlah & $\mathbf{2 8}$ & $\mathbf{1 0 0 , 0}$ & $\mathbf{4 0}$ & $\mathbf{1 0 0 , 0}$ \\
\hline
\end{tabular}

Berdasarkan Sikap siswa SMPIT Al Musabbihin dan SMPIT Namira tentang pentingnya konsumsi sayur dan buah setelah diberi pendidikan kesehatan menggunakan media audiovisual dan ceramah (posttest) menunjukkan bahwa setelah diberikan intervensi sebagian besar sikap siswa di SMPIT Al Musabbihin dalam kategori positif $(92,9 \%)$, bersikap negatif $(7,1 \%)$. Sikap siswa di SMPIT Namira sebagian besar positif $(76,7 \%)$, negatif $(23,3 \%)$.

\section{Perbedaan Sikap Siswa SMPIT Al Musabbihin dan Namira Pentingnya Konsumsi Sayur dan Buah Setelah Intervensi (Post test) \\ Perbedaan sikap siswa setelah diberikan intervensi dengan media}

audiovisual dan metode ceramah, dapat dilihat pada tabel berikut.

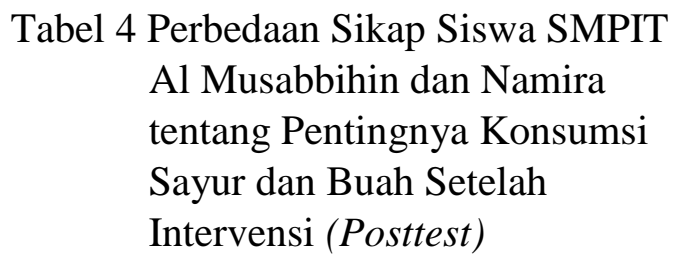

\begin{tabular}{cccccc}
\hline Variabel & $\begin{array}{c}\text { Mean } \\
\pm \text { SD }\end{array}$ & $\begin{array}{c}\text { Mean } \\
\text { Difference }\end{array}$ & t & df & $\begin{array}{c}\text { Sig } \\
(\mathbf{p})\end{array}$ \\
\hline Sikap siswa & 32,50 & & & & \\
SMPIT Al & $\pm 3,049$ & & & & \\
Musabbihin & & 3,067 & 3,0 & 56 & 0,0 \\
dan Namira & & & 34 & & 04 \\
& 29,43 & & & & \\
& $\pm 4,462$ & & & & \\
\hline
\end{tabular}

Berdasarkan hasil uji statistik perbedaan sikap siswa SMPIT Al Musabbihin dan siswa SMPIT Namira tentang pentingnya konsumsi sayur dan buah setelah diintervensi dengan metode audiovisual dan metode ceramah, menggunakan uji independent sample ttest diperoleh hasil bahwa terdapat perbedaan yang signifikan sikap siswa SMPIT Al Musabbihin dan Namira tentang pentingnya konsumsi sayur dan buah setelah diberi intervensi, $p=0,004<$ 0,05 .

\section{PEMBAHASAN}

\section{Pengaruh Metode Audiovisual dan Ceramah Terhadap Sikap Siswa}

Sikap merupakan reaksi respon yang masih tertutup dari seorang terhadap suatu stimulus atau objek. Mnurut Newcomb yang dikutip oleh Notoatmodjo (Notoatmodjo, 2013), sikap merupakan kesiapan atau kesediaan untuk bertindak, dan bukan merupakan pelaksanaan motif tertentu. Sikap belum merupakan suatu tindakan atau aktivitas, akan tetapi merupakan predisposisi tindakan suatu perilaku. Sikap masih merupakan reaksi 
tertutup, bukan merupakan reaksi terbuka atau tingkah laku terbuka (Ahmadi, 2013).

Hasil penelitian ini menunjukkan variabel sikap menunjukkan ada perbedaan sebelum dan setelah dilakukan intervensi, dengan nilai $\mathrm{p}=0,004<0,05$ yang berarti ada pengaruh metode audiovisual dalam meningkatkan sikap siswa terhadap pentingnya konsumsi sayur dan buah.

Sikap siswa di SMPIT Al Musabbihin tentang pentingnya konsumsi sayur dan buah sebelum diberi ceramah menunjukkan bahwa lebih banyak siswa yang memiliki sikap negatif dibandingkan sikap positif dilihat dari jawaban siswa tehadap kuesioner yang diberikan, demikian juga sikap siswa di SMPIT Namira lebih banyak yang memiliki sikap negatif dibandingkan yang memiliki sikap positif.

Hal ini terlihat dari jawaban-jawaban responden di SMPIT Al Musabbihin terhadap pernyataan sikap yang diajukan sebelum diberi intervensi bahwa lebih banyak responden menjawab 'sangat setuju' yaitu vitamin, mineral dan serat banyak terdapat di buah dan sayuran $(28,6 \%)$. Responden setuju bahwa buah yang baik dan bergizi adalah buah yang enak dan mahal harganya dan responden setuju mengonsumsi buah di pagi hari sangat baik karena buah memberi cukup energi sampai saatnya makan siang $(53,6 \%)$. Responden banyak yang tidak setuju bahwa jenis buah dan sayur yang dikonsumsi setiap hari haruslah beraneka ragam (64,3\%). Pernyataan yang paling banyak dijawab 'sangat tidak setuju' yaitu mengonsumsi jeruk tidak dapat mencegah kita dari sariawan dan bibir pecah-pecah $(10,7 \%)$.

Pernyataan variabel sikap yang paling banyak dijawab 'sangat setuju' oleh responden di SMPIT Namira yaitu mengonsumsi wortel dapat mencegah kita dari gangguan penglihatan dan meningkatkan daya tahan tubuh $(16,7 \%)$. Hal tersebut dikarenakan siswa banyak yang sudah tahu bahwa wortel merupakan salah satu sayuran yang dapat mencegah gangguan penglihatan.

Perubahan sikap siswa yang diperoleh merupakan hasil dari pendidikan kesehatan dengan media audiovisual. Media audiovisual sesuai untuk anak usia sekolah karena dapat mengembangkan imajinasi dan aktivitas belajar anak dalam suasana menyenangkan sehingga dapat merangsang minat belajar anak karena ditampilkan dalam bentuk animasi yang menarik dan mudah dipahami. Media ini cukup menyenangkan sesuai dengan tahap perkembangan kognitif anak usia sekolah yang mayoritas respondennya berumur 11-13 tahun berada dalam tahap operasional konkrit artinya aktivitas mental yang difokuskan pada objekobjek peristiwa nyata atau konkrit (Notoatmodjo, 2014).

Penelitian yang dilakukan oleh Siwi (2014) pada siswa kelas VI di SDN Seduri 1 Balongbendo Sidoarjo bahwa sikap siswa mengalami perubahan setelah 
diberikan pendidikan kesehatan mengenai jajanan sehat dengan media audio visual. Media audio visual berpengaruh terhadap sikap tentang jajanan sehat pada anak sekolah.

Hasil penelitian yang dilakukan Gustiara (2012) pada siswa SMA Negeri 1 Pekan Baru, untuk sikap responden terhadap sayuran dan buah, masih ada beberapa responden yang memiliki sikap yang kurang. Sikap merupakan reaksi yang masih tertutup dari seseorang terhadap stimulus atau objek. Sikap adalah pandangan, pendapat, tanggapan ataupun penilaian dan juga perasaan seseorang terhadap stimulus atau objek yang disertai dengan kecenderungan bertindak (Notoatmodjo, 2013). Hal tersebut yang mendukung terjadi perubahan sikap dari negatif menjadi positif pada sebagian besar responden. Nilai sikap responden setelah diberikan pendidikan kesehatan mayoritas menjadi meningkat dikarenakan responden sudah bisa menangkap seluruh hal positif yang mereka dapatkan dari intervensi. Setelah pengetahuan mereka cukup, emosional mereka bereaksi dengan stimulus yang ada. Media massa dan lembaga pendidikan juga mempunyai pengaruh besar dalam pembentukan sikap seseorang

Metode audio visual lebih menarik dibanding ceramah karena siswa saat ini khususnya siswa SMPIT Al Musabbihin lebih senang aktivitas menonton film dibandingkan dengan aktivitas membaca yang dianggap lebih membosankan. 152
Pembelajaran dengan metode audio visual dapat membangkitkan rangsangan indera penglihatan, pendengaran, perabaan, maupun penciuman atau kesesuaiannya dengan tingkatan belajar siswa. Metode audiovisual tidak menyebabkan siswa bosan tetapi tetap dapat membuat siswa antusias untuk mengikuti pelajaran sampai selesai terutama jika film yang disajikan menarik dengan bahasa yang mudah dimengerti dan dipahami oleh siswa seperti halnya tentang pentingnya konsumsi sayur dan buah.

Promosi kesehatan mempunyai peranan yang penting dalam proses pemberdayaan masyarakat yaitu memperoleh pembelajaran dari, oleh dan bersama masyarakat sesuai dengan lingkungan sosial budaya setempat, agar masyarakat dapat menolong dirinya sendiri di bidang kesehatan. Promosi kesehatan tidak lepas dari media karena melalui media, pesan-pesan yang disampaikan lebih menarik (Fitriani, 2015).

Berkaitan dengan teori yang digunakan dalam penelitian ini maka pemutaran film menjadi stimulus atau rangsangan dari luar bagi siswa untuk mengenal tentang pentingnya konsumsi sayur dan buah siswa selanjutnya respon yang dimunculkan organisme tanpa adanya stimulus spesifik yang berlangsung memaksa terjadinya respon tersebut. Terjadinya proses pengikatan stimulus baru dengan respon yang baru tentang pentingnya konsumsi sayur dan buah siswa akan membuat respon tertutup 
berupa pengetahuan dan sikap siswa tersebut. Organisme dihadapkan pada pilihan respon mana yang akan dipakainya untuk menanggapi suatu stimulus tentang pentingnya konsumsi sayur dan buah siswa. Keputusan respon mana yang dipilih tergantung kepada efeknya terhadap lingkungan atau konsekuensi yang mengikuti respon tersebut sehingga siswa memahami dengan baik tentang pentingnya konsumsi sayur dan buah siswa.

Peran guru dalam merubah sikap siswa tentang pentingnya konsumsi sayur dan buah penting dengan memberikan informasi kepada siswa bahwa mengonsumsi sayur dan buah sangat penting untuk kesehatan tubuh. Apalagi jika dilihat keadaan saat ini anak-anak khususnya remaja lebih suka makanmakanan cepat saji (fast food) dan jarang mengonsumsi sayur dan buah sehingga guru lebih ditantang untuk dapat menyampaikan informasi tentang pentingnya konsumsi sayur dan buah menggunakan media audiovisual karena jika dilihat dari hasil penelitian ini lebih banyak sikap siswa yang berubah menjadi positif setelah mendapatkan promosi kesehatan melalui media audiovisual yaitu pemutaran film animasi konsumsi sayur dan buah, dibandingkan dengan siswa yang mendapatkan informasi dari metode ceramah yang disampaikan oleh guru.

\section{KESIMPULAN DAN SARAN}

Media audiovisual efektif untuk merubah sikap siswa karena pembelajaran dengan metode audio visual dapat membangkitkan rangsangan indera penglihatan, pendengaran, perabaan, maupun penciuman atau kesesuaiannya dengan tingkatan belajar siswa, sikap positif terhadap pentingnya konsumsi sayur dan buah di SMPIT Al Musabbihin dan metode ceramah di SMPIT Namira tahun 2018.

Disarankan kepada kepala sekolah, guru-guru agar menggunakan media audio visual untuk merubah sikap siswa tentang pentingnya konsumsi sayur dan buah menjadi positif seluruhnya.

\section{DAFTAR PUSTAKA}

Adisasmoto. 2015. Promosi kesehatan. Cetakan Kedua. Yogyakarta: Gadjah Mada University Press.

Ahmadi, A. 2013. Psikologi Sosial: Suatu Pengantar. Cetakan Kedua. Jakarta: Rineka Cipta.

Angkowo, R. dan Kosasih, A. 2013. Optimalisasi Media Pembelajaran. Jakarta: Grasindo.

Ardianto, E. dan Erdinaya, L.K. 2015. Komunikasi Massa: Suatu Pengantar. Bandung: Remaja Rosdakarya.

Azwar, S. 2013. Sikap Manusia, Teori dan Pengukurannya. Cetakan XVII. Yogyakarta: Pustaka Pelajar.

Fitriani, S. 2015. Promosi Kesehatan. Cetakan Pertama. Yogyakarta: Penerbit Graha Ilmu.

Gustiara, I. 2012. Gambaran konsumsi sayuran dan buah pada siswa SMA Negeri 1 Pekan Baru tahun 2012. Medan : FKM USU.

Junaidi, I. 2012. Ensiklopedia Jus Sayur dan Buah. Cetakan Pertama. Jakarta: Bhuana Ilmu Populer.

Kemenkes RI. 2013. Riset Kesehatan Dasar Indonesia Tahun 2013. Jakarta: Kementerian Kesehatan Republik Indonesia.

Kemenkes RI. 2016. Pedoman Gizi Seimbang (Pedoman Teknis bagi 
Petugas dalam Memberikan Penyuluhan Gizi Seimbang). Jakarta : Direktorat Jenderal Bina Gizi dan KIA KKR Kementerian Kesehatan Republik Indonesia.

Nasution, D.Y. 2014. Efektivitas KIE (Komunikasi, Informasi dan Edukasi) Metode ceramah dan Pemutaran Film terhadap Pengetahuan dan Sikap Ibu Hamil tentang Zat Besi di Kecamatan Padangsidimpuan Tenggara Tahun 2014. Tesis. Medan: Program Studi S2 Kesehatan Masyarakat FKM Universitas Sumatera Utara.

Notoatmodjo, S. 2013. Kesehatan Masyarakat: Ilmu dan Seni. Edisi Revisi. Jakarta: Rineka Cipta.

. 2014. Promosi Kesehatan Teori dan Aplikasi. Cetakan Kedua. Jakarta: Rineka Cipta.

Novianto, R. 2016. Pengaruh Terpaan Media Terhadap Perubahan Sikap Dari Tayangan Sinetron '7 Manusia Harimau' Di Kalangan Remaja SMA Kota Bandung. e-Proceeding of Management : Vol.3, No.1 April 2016.

Nurul. 2015. Pengaruh Pemberian Media Animasi terhadap Perubahan Pengetahuan dan Sikap Gizi Seimbang pada Siswa Kelas VI SD Negeri Tanjung Duren Utara 01 Pagi Jakarta Barat.

Siwi, L.R. 2014. Meningkatkan Perilaku Konsumsi Jajanan Sehat Pada Anak Sekolah Melalui Media Audio Visual. Jurnal Pediomaternal. Oktober-April 2014; 3(1).

Warganegara, E. dan Nur, N.N. 2016. Faktor Risiko Perilaku Penyakit Tidak Menular. Majority. April 2016; 5(2): 88-9 